\title{
Modified Kidney Sodium Potassium Adenosine-Triphosphatase Kinetics in Protein Energy Malnutrition
}

\author{
S.K. SAMIUddin and B.S. NARASinga RaO* \\ National Institute of Nutrition, Indian Council of Medical Research, \\ Jamai-Osmania P.O., Hyderabad-500007, A.P., India
}

(Received April 11, 1986)

Summary Erythrocyte membrane and kidney microsomal Na, KATPases have been shown to be elevated in children suffering from kwashiorkor and in protein energy malnourished (PEM) rats. Kinetic properties of kidney microsomal $\mathrm{Na}$, K-ATPase were studied in PEM rats to understand further the mechanism of this elevated activity. From the Arrhenius plots no significant differences were seen in the critical temperature and energy of activation of $\mathrm{Na}, \mathrm{K}$-ATPase between the control (C), energyrestricted (ER), and protein-restricted (PR) rats. Changes in the apparent $\mathrm{K}_{0.5}$ values of $\mathrm{Na}^{+}, \mathrm{K}^{+}$, and ATP were of much smaller magnitude, and increased $V_{\max }$ was found to be mainly responsible for the observed increase in Na, K-ATPase activity in PEM rats. The Hill coefficient with ATP as substrate was found to be 1.62 in all three groups. $V_{\max } / K_{\mathrm{m}}$ : a broad index of physiological efficiency, remained unaltered with $\mathrm{K}^{+}$as a substrate in the ER rats, but was higher by $60 \%$ in PR rats as compared with the control value. In the $\mathrm{Na}^{+}$-activated component, the physiological efficiency in protein restriction was higher by $60 \%$ in relation to energy restriction. These results lead to the conclusion that the increased $\mathrm{Na}$, K-ATPase activity in kidney microsomal preparations, from PR rats is attributable to modifications in the enzyme site and that energy restriction, in fact, results in a lowering of the physiological efficiency of $\mathrm{Na}, \mathrm{K}$ ATPase by affecting the $\mathrm{Na}^{+}$-site. Altered lipid microenvironment if any, does not appear to contribute to changes in Na, K-ATPase activity in PEM since neither Arrhenius plots nor Hill coefficients (ATP) showed any modification.

Key Words: Na, K-ATPase, protein restriction, energy restriction

Sodium-potassium-activated adenosine triphosphatase (ATP-phosphohydro-

\footnotetext{
*To whom correspondence should be addressed.
} 
lase, EC 3.6.1.3: $\mathrm{Na}$, K-ATPase) a biochemical expression of the " $\mathrm{Na}^{+}$-pump," is involved in the uphill transport of $\mathrm{Na}^{+}$and $\mathrm{K}^{+}$across the plasma membrane [1, 2]. The enzyme system has a ubiquitous distribution in all mammalian cell membranes and is crucial to the maintenance of potential across the membrane via maintaining an ionic equilibrium. In performing this task in different cells, it contributes to the active $\mathrm{Na}^{+}$-reabsorption in the kidney and transmission of nerve impulses in the neuron [3]. Due to these vital functions this enzyme system is highly responsive to any perturbation in the cell, particularly the ones concerned with alterations in ion permeability. In addition, being an integral membrane protein, it also responds to an altered microenvironment, which is reflected mostly by modifications in Arrhenius and Hill plots [4, 5].

Our own interest in this transport system stems from an earlier study on protein energy malnutrition (PEM) amongst the pre-school children in many developing countries including India. Accumulation of fluid (edema) is one of the most obvious clinical signs in these patients. Ouabain-sensitive Na,K-ATPase activity in the leucocytes and erythrocytes of these patients seems to be elevated [6, 7]. In subsequent studies, this elevation in erythrocyte membrane Na,K-ATPase was shown to be an adaptation for preventing the continued cellular accumulation of $\mathrm{Na}^{+}$in these patients. A failure of such an adaptive mechanism causes intracellular accumulation of electrolytes and fluid causing edema [8-10].

In simultaneous studies using an experimental model of this disorder in which rats receiving a protein-deficient diet simulate some of the clinical signs of human kwashiorkor [11], we found similar elevation of kidney microsomal Na,K-ATPase in PEM rats [12].

$\mathrm{Na}, \mathrm{K}-\mathrm{ATPa} e$, an integral membrane protein with vectorial localisation across the membrane, is activated by $\mathrm{Na}^{+}$from the inner surface of the membrane. $\mathrm{Na}^{+}$is considered to activate phosphorylation step and $\mathrm{K}^{+}$the dephosphorylation step from the outer surface of the membrane [9]. The aim of the present experiment was to determine a possible mechanism for the increased kidney microsomal $\mathrm{Na}, \mathrm{K}-\mathrm{ATPase}$ activity in PEM rats from a study of its kinetic characteristics.

\section{MATERIALS AND METHODS}

Details of the diet compositions and rats used in these studies have been reported earlier $[13,14]$. Briefly, wealing Wistar strain male rats were fed a $22 \%$ casein diet till they attained an average body weight of $90 \mathrm{~g}$. They were then divided into 3 groups. Group I, the control (C), received 22\% casein diet ad lib; group II rats, the same diet in restricted amounts so as to maintain their average body weight similar to that of group III which received a $1 \%$ casein diet and served as a protein-restricted group (PR). Group II thus served as the energy-restricted group (ER). The rats were maintained on their respective diets for 7-9 weeks, after which time the PR rats show major symptoms of kwashiorkor [11].

All the reagents used were of analytical grade. Ouabain and ATP were ob- 
tained from Sigma Chemical Co., (St. Louis, MO). Sodium ATP was converted to Tris-ATP by the method of Epstein and Whittam [15] for all kinetic studies. Sodium ortho vanadate (pure form) was a gift from Dr. Ramanadham (NIH, Bethesda).

Enzyme preparation. Rats were fasted overnight and sacrificed by cervical dislocation. The kidneys were removed and immersed immediately in ice-cold homogenising medium containing $0.25 \mathrm{M}$ sucrose, $0.03 \mathrm{~m}$ histidine- $\mathrm{NaOH}$ buffer (pH 7.4), and $0.001 \mathrm{M}$ EDTA. They were then decapsulated, freed from adhering blood, weighed, and homogenised in 9 vols of homogenising medium in a motor-driven Teflon pestle for $1 \mathrm{~min}$. The homogenate was centrifuged at $600 \times g$ for $10 \mathrm{~min}$. The supernatant was removed, and the pellet was washed with 5 vols of homogenising medium and again centrifuged at $600 \times g$ for $15 \mathrm{~min}$. The pellet was discarded and the supernatant further centrifuged at $105,000 \times g$ for $1 \mathrm{~h}$. The membrane-rich pellet was resuspended in homogenising medium to give approximately $10 \mathrm{mg}$ protein/ml, frozen and stored overnight at $-20^{\circ} \mathrm{C}$, and then analyzed for enzyme activity.

Assay of $\mathrm{Na}, \mathrm{K}$-ATPase activity. The enzyme activity was assayed with 50 $60 \mu \mathrm{g}$ of kidney microsomes in a reaction medium containing $20 \mathrm{~mm}$ Tris- $\mathrm{HCl}$ ( $\mathrm{pH}$ 7.4), $140 \mathrm{~mm} \mathrm{NaCl}, 14 \mathrm{~mm} \mathrm{KCl}, 3 \mathrm{~mm} \mathrm{MgCl}_{2}, 3 \mathrm{~mm}$ Tris-ATP, and $0.2 \mathrm{~mm}$ EDTA in a final volume of $0.5 \mathrm{ml}$. Ouabain, when used, was at a concentration of $2 \mathrm{~mm}$. Reactions were allowed to proceed for $10 \mathrm{~min}$ at $37^{\circ} \mathrm{C}$ before they were terminated by addition of $0.5 \mathrm{ml}$ of $10 \%$ TCA. Tubes were then centrifuged to sediment the precipitate and the $P_{1}$ released by the enzyme action was measured in the supernatant by the method of Fiske-Subbarow [16]. Proteins were estimated by Lowry's method [17]. Na,K-ATPase activity was defined as the difference between activities in the absence and presence of ouabain. One unit of enzyme was defined as that amount releasing $1 \mu \mathrm{mol}$ of $P_{\mathbf{i}}$ per hour per mg protein of microsomes.

Arrhenius plots, transition temperature, and activation energies. Arrhenius plots were prepared by assaying the enzyme activity at different temperatures ranging between 2 and $30^{\circ} \mathrm{C}$ at $4-5^{\circ} \mathrm{C}$ intervals. At lower temperatures (between $2-10^{\circ} \mathrm{C}$ ) the reactions were continued for up to $30 \mathrm{~min}$, and at higher temperatures, for $10 \mathrm{~min}$. For the calculation of the transition temperature $\left(T_{\mathbf{c}}\right)$ the logarithm of the specific activity value at each temperature was plotted against the reciprocal of the absolute temperature. The values of $T_{\mathbf{c}}$ were directly read from the graph and the activation energies above and below the $T_{\mathrm{c}}$ were calculated by the Arrhenius equation.

Enzyme kinetics. Kinetic characteristics of the enzyme from the three groups of rats were studied with, $\mathrm{Na}^{+}, \mathrm{K}^{+}$, and ATP as substrates. Enzyme activity was measured at various concentrations of $\mathrm{Na}^{+}(2-100 \mathrm{~mm}), \mathrm{K}^{+}(0.5-20 \mathrm{~mm})$, and ATP (0.1-4 mM) while keeping the other two constant. The activity at any concentrations of $\mathrm{Na}^{+}, \mathrm{K}^{+}$, or ATP was taken as the difference between the activity at that concentration and that in the absence of the ion.

Vol. 1, No. 3, 1986 
Effect of $1 \mu \mathrm{M}$ vanadate [Sodium ortho vanadate (V)] on Na,K-ATPase from the three groups of rats was studied at different concentrations of $\mathrm{Na}^{+}$. Microsomes were incubated with $1 \mu \mathrm{M}$ vanadate for $15 \mathrm{~min}$ at $37^{\circ} \mathrm{C}$ before the start of the reaction.

\section{RESULTS}

The Arrhenius plots of Na,K-ATPase from the 3 groups of rats gave biphasic curves with a deflection point at a certain temperature called the transition temperature $\left(T_{\mathbf{c}}\right)$. This temperature depends upon and reflects the composition of the membrane.

From the results presented in Table 1 it can be seen that the $T_{\mathrm{c}}$ of Na,K-ATPase was not altered due to food or protein restriction. The activation energies $\left(E_{\mathrm{a}}\right)$ calculated from the slopes of the curves using the Arrhenius equation were not different above the $T_{\mathrm{c}}$ but below the $T_{\mathrm{c}}$ the activation energy in PR rats was higher compared with the value in the control. In ER also the activation energy was higher, but not statistically so.

Table 1. Critical temperature $\left(T_{\mathrm{c}}\right)$ and activation energies $\left(E_{\mathrm{a}}\right)$ of kidney microsomal $\mathrm{Na}$, K-ATPase from PEM rats.

\begin{tabular}{llllc}
\hline Group & $N$ & $T_{\mathrm{c}}\left({ }^{\circ} \mathrm{C}\right)$ & $E_{\mathrm{a}}\left(>T_{\mathrm{c}}\right)$ & $E_{\mathrm{a}}\left(<T_{\mathrm{c}}\right)$ \\
& & \multicolumn{2}{c}{$(\mathrm{Kcal} / \mathrm{mol})$} \\
\hline C & 6 & $17.7 \pm 0.50$ & $4.2 \pm 0.34$ & $22.7 \pm 1.19$ \\
ER & 5 & $17.0 \pm 0.80$ & $4.6 \pm 0.50$ & $25.2 \pm 1.37$ \\
PR & 5 & $17.2 \pm 0.40$ & $4.4 \pm 0.50$ & $26.4 \pm 1.40^{*}$ \\
\hline
\end{tabular}

Values are means \pm SEM. $T_{\mathrm{c}}$ and $E_{\mathrm{a}}$ are calculated from the Arrhenius plots drawn from the mean values of activities. $N$, Number of rats in each group; ${ }^{*} p<0.05$ vs. C.

Table 2. Kinetic constants of kidney microsomal Na,K-ATPase in PEM rats.

\begin{tabular}{|c|c|c|c|c|c|c|c|c|}
\hline \multirow[b]{2}{*}{ Group } & \multicolumn{3}{|c|}{$\mathrm{Na}^{+}$} & \multicolumn{3}{|c|}{$\mathrm{K}^{+}$} & \multicolumn{2}{|c|}{ ATP } \\
\hline & $V_{\max }{ }^{\mathrm{a}}$ & $\begin{array}{l}K_{\mathrm{m}} \\
(\mathrm{mM})\end{array}$ & $\begin{array}{l}V_{\max } / \\
K_{\mathrm{m}}\end{array}$ & $V_{\max }{ }^{\mathrm{a}}$ & $\begin{array}{l}K_{\mathrm{m}} \\
(\mathrm{mM})\end{array}$ & $\begin{array}{l}V_{\max } / \\
K_{\mathrm{m}}\end{array}$ & $\begin{array}{l}K_{\mathrm{m}} \\
(\mathrm{mM})\end{array}$ & $\begin{array}{l}\text { Hill } \\
\text { coeffi- } \\
\text { cient } \\
(\Delta H)\end{array}$ \\
\hline $\mathrm{C}$ & $\begin{array}{c}15.3 \pm 1.00 \\
(9)\end{array}$ & $8.1 \pm 1.64$ & 1.897 & $\begin{array}{c}25.6 \pm 0.83 \\
(6)\end{array}$ & $3.6 \pm 0.83$ & 7.114 & $\begin{array}{l}2.1 \pm 0.04 \\
(6)\end{array}$ & $1.6 \pm 0.06$ \\
\hline ER & $\begin{array}{c}18.8 \pm 2.00 \\
(10)\end{array}$ & $12.2 \pm 1.30$ & 1.528 & $\begin{array}{c}31.6 \pm 3.40 \\
(6)\end{array}$ & $3.8 \pm 0.65$ & 8.412 & $\begin{array}{c}1.6 \pm 0.03 \ddagger \\
(6)\end{array}$ & $1.6 \pm 0.02$ \\
\hline PR & $\begin{array}{c}20.8 \pm 1.56 \\
(10) \dagger\end{array}$ & $8.6 \pm 0.30$ & 2.434 & $\begin{array}{c}29.0 \pm 0.80 \\
(5)\end{array}$ & $2.4 \pm 0.29$ & 11.930 & $\begin{array}{c}1.6 \pm 0.05 \ddagger \\
(6)\end{array}$ & $1.6 \pm 0.06$ \\
\hline
\end{tabular}

Values are means \pm SEM. Numbers in parentheses indicate the number of rats in each group. a $\mu \mathrm{mol} \mathrm{Pi/h/mg} \mathrm{protein.} \mathrm{Apparent} K_{\mathrm{m}}$ 's for $\mathrm{Na}^{+}$and $\mathrm{K}^{+}$were derived from LineweaverBurk plots. $K_{\mathrm{m}}$ for ATP was calculated from Hill plots. $V_{\mathrm{max}} / K_{\mathrm{m}}$ were calculated from mean values of $V_{\max }$ and $K_{\mathrm{m}} \uparrow p<0.01$ vs. $\mathrm{C} ; \ddagger p<0.001$ vs. C. 
Table 3. Effect of vanadate on the kinetic constants of kidney microsomal Na,K-ATPase from PEM rats using $\mathrm{Na}^{+}$as substrate.

\begin{tabular}{|c|c|c|c|c|c|c|c|}
\hline \multirow[b]{2}{*}{ Group } & \multirow[b]{2}{*}{$N$} & \multicolumn{3}{|c|}{ No vanadate } & \multicolumn{3}{|c|}{ Vanadate $(1 \mu \mathrm{M})$} \\
\hline & & $\begin{array}{c}K_{\mathrm{m}} \\
\mathrm{Na}^{+}(\mathrm{mM})\end{array}$ & $V_{\max }{ }^{\mathrm{a}}$ & $V_{\max } / K_{\mathrm{m}}$ & $\begin{array}{c}K_{\mathrm{m}} \\
\mathrm{Na}^{+}(\mathrm{mM})\end{array}$ & $V_{\max }{ }^{a}$ & $V_{\max } / K_{\mathrm{m}}$ \\
\hline $\mathrm{C}$ & 9 & $8.1 \pm 1.20$ & $15.3 \pm 1.00$ & $2.0 \pm 0.23$ & $7.2 \pm 1.13$ & $6.1 \pm 0.09 b$ & $0.9 \pm 0.14^{b}$ \\
\hline ER & 10 & $12.3 \pm 1.34$ & $18.8 \pm 2.01$ & $1.7 \pm 0.28$ & $17.9 \pm 3.80^{*}$ & $8.2 \pm 1.14 b$ & $0.5 \pm 0.09 *, b$ \\
\hline PR & 10 & $8.6 \pm 0.31$ & $20.3 \pm 15.7 \dagger$ & $2.8 \pm 0.45$ & $12.9 \pm 1.00 \ddagger$ & $8.3 \pm 0.36^{b}$ & $0.7 \pm 0.09 \mathrm{~b}$ \\
\hline
\end{tabular}

Values are means \pm SEM. a $\mu \mathrm{mol} \mathrm{Pi} / \mathrm{h} / \mathrm{mg}$ protein; ${ }^{\mathrm{b}} p<0.002$ vs. no vanadate; ${ }^{*} p<0.02$ vs. $\mathrm{C} ; \dagger p<0.01$ vs. $\mathrm{C} ; \ddagger p<0.002$ vs. $\mathrm{C}$.

With $\mathrm{Na}^{+}$and $\mathrm{K}^{+}$the enzyme followed Michaelis Menten kinetics and could be fitted in the Lineweaver Burk plots. With ATP, the enzyme gave a sigmoidal curve and was linearised by Hill plots, and Hill coefficients were determined from the slopes of these plots.

As shown in Table 2, the apparent $K_{\mathrm{m}}$ 's of Na,K-ATPase for ATP as calculated from the Hill plots were significantly lower in both ER and PR rats compared with that of the control, indicating an increased affinity of the enzyme for ATP in these two groups. However, the Hill coefficients were not altered. On the other hand the $K_{\mathrm{m}}$ values for $\mathrm{K}^{+}$and $\mathrm{Na}^{+}$did not change due to PR but the affinity for $\mathrm{Na}^{+}$was found to be lower in ER rats. The $V_{\max }$ with both $\mathrm{Na}^{+}$and $\mathrm{K}^{+}$were higher in ER and PR rats though a statistically significant difference was observed only with $\mathrm{Na}^{+}$.

Vanadate showed a concentration-dependent inhibition of the enzyme activity from all the three groups. However, when tested at different concentrations of $\mathrm{Na}^{+}$, vanadium behaved as a noncompetitive inhibitor of $\mathrm{Na}, \mathrm{K}$-ATPase from control animals, whereas toward the enzymes from the experimental rats, it behaved as a mixed type of inhibitor; i.e., $K_{\mathrm{m}}$ was increased, but $V_{\max }$ was decreased (Table 3). The extent of inhibition (percentage wise) of $V_{\max }$ by vanadium was not much different among the three groups. However $V_{\max } / K_{\mathrm{m}}$, which broadly reflects physiological capacity of the system, was more affected by vanadium in ER $(71 \%)$ and PR rats $(76 \%)$ than in the controls on a normal diet $(55 \%)$.

\section{DISCUSSION}

$\mathrm{Na}, \mathrm{K}-\mathrm{ATPa} e$ activity has been shown to be altered in many pathological conditions [18-21], and in most of these cases the alteration is reversible and returns to normal after treatment. Such alterations may result from changes in the membrane microenvironment or from modifications in enzyme kinetics itself, though enhanced synthesis of enzymes cannot be ruled out.

It has been well established that the activity of $\mathrm{Na}, \mathrm{K}$-ATPase is influenced greatly by the physical state of the membrane lipids, which in turn affect the fluidity of the membrane $[4,22]$. A very important tool for studying membrane 
fluidity is the Arrhenius plot of Na,K-ATPase [23]. Most membrane-bound enzymes show a transition temperature $\left(T_{\mathbf{c}}\right)$ in their Arrhenius plots. This has been shown to be not due to any effect of temperature on the protein moiety of the enzyme, but rather to changes in the physical properties of membrane lipids surrounding and interacting with the enzyme. An inherent change in the physical state of the lipids shifts the $T_{\mathrm{c}}$ away from the normal value. The present experiment did not show any such change in the $T_{\mathrm{c}}$ among the groups indicating that the fluidity of the membrane is not much affected and thus may not be responsible for the observed increase in enzyme activity due to food restriction. Though a slight increase in the activation energies below the $T_{\mathrm{c}}$ was observed in ER and PR groups, this may not reflect any significant changes in the lipid microenvironment of the enzyme.

Kinetic studies of the enzyme with $\mathrm{Na}^{+}, \mathrm{K}^{+}$, and ATP as substrates showed a significant increase in the affinity for ATP with enzyme from both ER and PR groups. In erythrocytes of kwashiorkor children, on the other hand, we had observed an increase in the affinity for $\mathrm{Na}^{+}$[9]. There is evidence for more than one ATP binding site per molecule of the enzyme. Hill coefficients $(\Delta H)$ calculated from Hill plots with ATP as substrate further strengthen this. However, there were no differences in the $\Delta H$ values among the three groups. The increase in affinity for ATP in PEM group suggests that there may be an enhancement in the phosphorylation step of the two-step mechanism of enzyme reaction as proposed by Albers and Post et al. [24, 25].

Vanadate potently inhibits $\mathrm{Na}, \mathrm{K}-\mathrm{ATPa}$ e from the cytoplasmic side of the membrane. The extent of inhibition thus depends on the membrane permeability to vanadate [26]. It stabilizes the pump in the $\mathrm{E}_{2} \mathrm{~K}$ configuration and slows the conformational change of $\mathrm{E}_{2} \mathrm{~K} \rightarrow \mathrm{E}_{1} \mathrm{~K}$ [27].

More importantly, Patrick has implicated vanadate to play an important role in edema formation in kwashiorkor [28]. In the light of observations made by Day and colleagues [29] that vanadate inhibits the extrusion of $\mathrm{Na}^{+}$into the basolateral spaces of the kidney tubule, it was suggested that vanadate might be the factor that may finally end the controversy surrounding the pathogenesis of edema [30].

Bond et al. on the other hand, have shown that at low $\mathrm{Na}^{+}$concentrations $\mathrm{Na}, \mathrm{K}$-ATPase is extremely sensitive to vanadate. At higher concentrations $\mathrm{Na}^{+}$ occupies the low-affinity site and reverses the inhibition of Na,K-ATPase by vanadate competitively [31]. In the present experiment also, vanadate had a greater inhibitory effect on the enzyme at low than at high $\mathrm{Na}^{+}$concentrations (data not presented). Moreover, the different effect of vanadate on the enzyme from the three groups points to membrane modification on the inner side, i.e., the vanadium binding site.

The above experiments thus point out that the observed changes in enzyme activity in PEM rats may not be due to changes in membrane fluidity as was anticipated, but rather due to slight modification on the inner side of the membrane 
leading to changes in enzyme kinetics with ATP. This probably enhances the phosphorylation step of Na,K-ATPase which is supposed to be rate-limiting. Observations on the vanadate effect further strengthen this assumption.

\section{REFERENCES}

1. Skou, J.C. (1957): The influence of some cations on an adenosine triphosphatase from peripheral nerves. Biochim. Biophys. Acta, 23, 394-401.

2. Jorgensen, P.L., and Skou, J.C. (1971): Purification and characterization of Na,K-ATPase. 1. The influence of detergents on the activity of $\mathrm{Na}, \mathrm{K}$-ATPase in preparations from the outer medulla of rabbit kidney. Biochim. Biophys. Acta, 233, 366-380.

3. Sweadner, K.J., and Goldin, S.M. (1980): Active transport of sodium and potassium ions. N. Engl. J. Med., 302, 777-783.

4. Charnock, J.S., Cook, D.A., Almedia, A.F., and Rebecca, T. (1973): Activation energy and phospholipid requirement of membrane-bound adenosine triphosphatases. Arch. Biochem. Biophys., 159, 393-399.

5. Farias, R.N. (1980): Membrane co-operative enzymes as a tool for the investigation of membrane structure and related phenomena. Adv. Lipid Res., 17, 251-282.

6. Partrick, J. (1977): Death during recovery from severe malnutrition and its possible relationship to sodium pump activity in the leucocyte. Br. Med. J., 1, 1051-1054.

7. Kaplay, S.S. (1978): Erythrocyte membrane $\mathrm{Na}^{+}$and $\mathrm{K}^{+}$activated adenosine triphosphatase in protein calorie malnutrition. Am. J. Clin. Nutr., 31, 579-584.

8. Kaplay, S.S., and Ramanadham, M. (1978): High erythrocyte membrane $\left(\mathrm{Na}+\mathrm{K}^{+}\right)$-ATPase in kwashiorkor in vivo reversal by diuretic. Clin. Chim. Acta, 88, 89-92.

9. Kaplay, S.S. (1979): Modified kinetics of erythrocyte membrane $\mathrm{Na}^{+}-\mathrm{K}^{+}$adenosine triphosphatases in protein energy malnutrition. Biochem. Med., 22, 282-287.

10. Kaplay, S.S. (1979): Erythrocyte ion transport in protein-energy malnutrition. Am. J. Clin. Nutr., 32, 722-723.

11. Ramanadham, M., and Kaplay, S.S. (1975): Rat liver mitochondrial ATPase in experimental protein energy malnutrition. Nutr. Rep. Int., 12, 93-100.

12. Pimplikar, S.W., and Kaplay, S.S. (1981): Kidney, liver, and erythrocyte membrane Na,Kadenosine triphosphatase in protein energy malnourished rats. Biochem. Med., 26, 12-19.

13. Ramanadham, M., and Kaplay, S.S. (1979): Response of oxidative phosphorylation in liver of protein energy malnourished rats. Nutr. Metab., 23, 235-240.

14. Samiuddin, S.K., and Kaplay, S.S. (1984): Kidney mitochondrial respiration in protein and energy malnourished rats. Biochem. Med., 31, 10-20.

15. Epstein, F.H., and Whittam, R. (1966): The mode of inhibition by calcium of cell membrane adenosine-triphosphatase activity. Biochem. J., 99, 232-238.

16. Fiske, C.H., and Subbarow, Y. (1925): The colorimetric determination of phosphorus. $J$. Biol. Chem., 66, 375-380.

17. Lowry, O.H., Rosebrough, N.J., Farr, A.L., and Randall, R.J. (1951): Protein measurement with the Folin phenol reagent. J. Biol. Chem., 193, 265-275.

18. Nakao, K., Kurashina, S., and Nakao, M. (1967): Adenosine triphosphatase activity of erythrocyte membrane in hereditary spherocytosis. Life Sci., 6, 595-600.

19. Cole, C.H., and Waddell, R.W. (1976): Alterations in intracellular sodium concentration and ouabain sensitive ATPase in erythrocyte from hyperthyroid patients. J. Clin. Endocrinol. Metabol., 42, 1056-1063.

20. Smith, E.K.M., Welt, L.G., and Czerwinsky, A. (1967): A reversible defect of membrane ATPase in the red cells of uremic patients. Clin. Res., 15, 51-58.

Vol. 1, No. 3, 1986 
21. Dunn, M.J. (1968): Alterations of the red blood cell sodium transport during malarial infection. Clin. Res., 16, 382.

22. Sandermann, H., Jr. (1978): Regulation of membrane enzymes by lipids. Biochim. Biophys. Acta, 515, 209-237.

23. Nemat-Gorgani, M., and Meisami, E. (1979): Use of Arrhenius plots of Na-K ATPase and acetylcholinesterase as a tool for studying changes in lipid-protein interactions in neuronal membranes during brain development. J. Neurochem., 32, 1027-1032.

24. Albers, R.W. (1967): Biochemical aspects of active transport. Ann. Rev. Biochem., 36, 727756.

25. Post, R.L., Hegyvary, C., and Kume, S. (1972): Activation by adenosine triphosphate in the phosphorylation kinetics of sodium and potassium ion transport adenosine triphosphatase. J. Biol. Chem., 247, 6530-6540.

26. Grantham, J.J. (1980): The renal sodium pump and vanadate. Am. J. Physiol., 239, F97F106.

27. Karlish, S.J.D., Beauge, L.A., and Glynn, I.M. (1979): Vanadate inhibits $\left(\mathrm{Na}^{+}+\mathrm{K}^{+}\right)$ATPase by blocking a conformational change of unphosphorylated form. Nature, 282, 333-336.

28. Patrick, J. (1979): Oedema in protein energy malnutrition: the role of sodium pump. Proc. Nutr. Soc., 38, 61-68.

29. Day, H., Middendorf, D., Lukert, B., Heinz, A., and Grantham, J. (1980): The renal response to intravenous vanadate in rats. J. Lab. Clin. Med., 96, 382-395.

30. Editorial (1981): Nutritional Oedema, Albumin and Vanadate. Lancet, 1, 646-647.

31. Bond, G.H., and Hudgins, P.M. (1982): Low affinity $\mathrm{Na}^{+}$sites on $\left(\mathrm{Na}^{+}+\mathrm{K}^{+}\right)$-ATPase modulate inhibition of $\mathrm{Na}^{+}$-ATPase activity by vanadate. Biochim. Biophys. Acta, 687, 310-314. 